Tropical Journal of Pharmaceutical Research September 2019; 18 (9): 1903-1907

ISSN: $1596-5996$ (print); 1596-9827 (electronic)

(C) Pharmacotherapy Group, Faculty of Pharmacy, University of Benin, Benin City, 300001 Nigeria.

Available online at http://www.tjpr.org

Original Research Article

http://dx.doi.org/10.4314/tjpr.v18i9.17

\title{
Protective effect of Acorus tatarinowii extract against alzheimer in 3xTg-AD mice
}

\author{
Cen $\mathrm{Su}^{1}$, Ping $\mathrm{Niu}^{2 *}$, Yao-ming $\mathrm{Xu}^{3}$, Ye Feng ${ }^{2}$, Hai-ping $\mathrm{Xia}^{1}$ \\ ${ }^{1}$ Department of Neurology, the Fourth Hospital of Jiangsu University, Zhenjiang 212001, ${ }^{2}$ Department of Neurology, the \\ General Hospital of Shenyang Military, Shenyang110004, ${ }^{3}$ Department of Neurology, Tongliao Hospital of Inner Mongolia \\ Autonomous Region, Tongliao 028000, China
}

*For correspondence: Email: niuping494@126.com; Tel: +86051184425614

Sent for review: 20 June 2018

Revised accepted: 23 August 2019

\begin{abstract}
Purpose: To investigate the protective effect of Acorus tatarinowii extract (ATE) against Alzheimer's disease in $3 \times T g-A D$ mice.

Method: The cognitive function of 3xTg-AD mice was assessed using Morris water maze test. The levels of the amyloid beta deposits and NeuN in the hippocampus were evaluated by immunohistochemical assay while brain neurotrophic derived factor (BDNF) and tyrosine kinase $B$ (TrkB) expressions were determined by western blot analysis.

Results: ATE treatment significantly ameliorated learning and memory deficits in AD mice, as shown by increased time spent in the target zone during probe tests. The escape latency in animals treated with $600 \mathrm{mg} / \mathrm{kg}$ ATE (24.8 $\pm 1.3 \mathrm{~s})$ was significantly increased relative to ontreated $3 \times \mathrm{Tg}-\mathrm{AD}$ mice $(8.5 \pm 1.0$ $s, p<0.01)$. In addition, ATE significantly decreased $A \beta$ deposits, increased NeuN-positive cells, and upregulated the expression of BDNF $(1.9 \pm 0.4, p<0.05)$ and TrkB $(1.9 \pm 0.2, p<0.05)$ in $3 \times \operatorname{Tg} A D$ mice.

Conclusion: These results suggest that ATE treatment may be a useful strategy for managing memory impairment induced by several neurodegenerative diseases.
\end{abstract}

Keywords: Acorus tatarinowii, Alzheimer's disease, Neurodegenerative diseases, Memory impairment, NeuN-positive cells, Amyloid beta deposits

This is an Open Access article that uses a fund-ing model which does not charge readers or their institutions for access and distributed under the terms of the Creative Commons Attribution License (http://creativecommons.org/licenses/by/4.0) and the Budapest Open Access Initiative (http://www.budapestopenaccessinitiative.org/read), which permit unrestricted use, distribution, and reproduction in any medium, provided the original work is properly credited.

Tropical Journal of Pharmaceutical Research is indexed by Science Citation Index (SciSearch), Scopus, International Pharmaceutical Abstract, Chemical Abstracts, Embase, Index Copernicus, EBSCO, African Index Medicus, JournalSeek, Journal Citation Reports/Science Edition, Directory of Open Access Journals (DOAJ), African Journal Online, Bioline International, Open-J-Gate and Pharmacy Abstracts

\section{INTRODUCTION}

Alzheimer's disease $(A D)$ is the most common form of dementia in the elderly and accounts for between 50 and $75 \%$ of all cases. By 2030, it is estimated that more than 65 million people will be affected by dementia, with projections almost doubling every 20 years. Alzheimer's disease is a progressive neurodegenerative disorder characterized, at least in part, by abnormal accumulation of $\beta$-amyloid peptide $(A \beta)$ in the brain [1]. The accumulated $A \beta$ is believed to play an important role in the pathogenesis of $A D$ [2]. Thus, $A \beta$ continues to be an important target for prevention and treatment of $A D$ [3].

Alzheimer's disease is the most common form of dementia relating to memory and cognitive decline. Alzheimer's disease is a progressive 
neurodegenerative disease in which dementia symptoms gradually worsen over the years [4]. Classical biochemical hallmarks of $A D$ include the accumulation of amyloid beta $(A \beta)$ peptide oligomers and soluble hyperphosphorylated tau [5]. Brain-derived neurotrophic factor (BDNF) is a small dimeric protein, it acts through high affinity binding with its receptor, tyrosine kinase $\mathrm{B}$ (TrkB). BDNF modulates neuronal growth and survival, and BDNF is implicated in learning and memory processes; therefore, dysfunction in BDNF is associated with cognitive deficits. In particular, BDNF is involved in the AD-related decline of neurogenesis, and levels of nerve growth factor are also diminished with $A D$ [6].

Medical treatment of AD patients is an increasing burden every year. In clinically, there are a variety of drugs available for $A D$, such as cholinesterase inhibitors, glutamate receptor antagonists, and free radical scavengers. However, these drugs do not closely target the pathogenesis of the disease, and have numerous side effects [7]. Therefore, it is extremely important to elucidate the mechanism of $A D$ pathophysiology to find a new drug for treatment.

Acorus tatarinowii, has been used in China in the treatment of various disorders, including stressinduced physiological changes, inflammation, hypertension, and cancer. Acorus tatarinowii extract has been reported to have anti-oxidant [8], immunomodulatory [9], and anti-mutagenic activities [10]. In this study, the neuroprotective effects of ATE on learning and memory deficits in a triple-transgenic mouse model of Alzheimer's disease (3xTg-AD) which expresses APP swe , $\mathrm{PS}_{\mathrm{M} 146 \mathrm{~V}}$, and tau $\mathrm{P}_{301 \mathrm{~L}}[11]$ was studied.

\section{EXPERIMENTAL}

\section{Plant material}

The plant material, Acorus tatarinowii collected from Dali City, Yunnan Province in China in October 2017. Taxonomic identification of the plant was performed by Professor Gang Wang of Jiangsu University, in China. A voucher specimen (no. ATE 201710004) was deposited in the herbarium of College of Pharmacy, Jiangsu University, China for future reference. The herbal samples Acorus tatarinowii were dried in an oven. Acorus tatarinowii extract (ATE) was obtained by steeping the dried Acorus tatarinowii in water at $60{ }^{\circ} \mathrm{C}$. It was repeated for three times, each for one hour before first drying in an oven and then freeze-drying the ATE thus obtained. One gram powder was equivalent to about $1.4 \mathrm{~g}$ crude samples. The yield was $71.43 \%$.

\section{Animals}

Alzheimer's disease (3xTg-AD) mice carrying a mutant APP (KM670/671NL), a human mutant PS1 (M146V) knock-in, and tau (P301L) transgenes (B6; 129-Psen $1^{\text {tm1Mpm }} \mathrm{Tg}$ (APPSwe, tauP301L) $1 \mathrm{Lfa} / \mathrm{J}$ ) were purchased from the Animal Research Institute, Nanjing University (Nanjing, China). The non-transgenic littermates were used as wild type (WT) controls. All animals were kept in a pathogen-free environment on a $12 \mathrm{~h}$ light/dark cycle and had access to food and water ad libitum.

\section{Animal groups}

The mice were randomly divided into four groups as follows: (1) saline treated WT group (WT, $n=$ 8); (2) saline-treated $3 \times \operatorname{Tg}$ group ( $3 \times \mathrm{Tg}, \mathrm{n}=8$ ); (3) $300 \mathrm{mg} / \mathrm{kg}$ ATE-treated $3 \times \mathrm{Tg}$ group (3xTgp + ATE $300, \mathrm{n}=8$ ), and (4) $600 \mathrm{mg} / \mathrm{kg}$ ATE-treated $3 \times T g$ group (3xTgp + ATE 600, $n=8$ ). Starting at 3 months of age, mice received PBS and ATE once a week for 3 months until they were 6 months old. Drugs were dissolved in water, and administered using a $5-\mathrm{ml}$ syringe with a $2-\mathrm{cm}$ long gavage needle through the mouth to the mouth once daily for 3 weeks. The animal experiment was approved by the Animal Care and Use Committee of the Fourth Hospital of Jiangsu University (approval no. 20151005), and was carried out in compliance with the Directive 2010/63/EU on the handling of animals used for scientific purposes [12].

\section{Water maze test}

A modified version of the water maze procedure described by Morris was used to test cognitive function [13]. The water in the pool was maintained at $22 \pm 2{ }^{\circ} \mathrm{C}$ and mixed with $1 \mathrm{~kg}$ of powdered skim milk to make the water opaque. During testing in the water maze, a platform (6 $\mathrm{cm}$ in diameter) was fixed $1 \mathrm{~cm}$ below the surface of the water at identical location within the pool. The pool was surrounded by differing extra-maze cues. All mice were subjected to four trials per day at intervals of $15 \mathrm{~min}$ for four consecutive days. The proportion of time spent searching for the platform in the training quadrant, i.e., the previous location of the platform, was used as a measure of memory retention.

\section{Western blotting}

At the end of the experiment, the mice were sacrificed by decapitation and the brains were rapidly removed and placed on ice. The hippocampus was quickly dissected by a scalpel 
and stored at $-80{ }^{\circ} \mathrm{C}$ fridge until use. The hippocampal tissue was homogenized in PROPREPTM Protein Extraction Solution (Shanghai Shengong, Shanghai, China). The homogenates were subsequently centrifuged at $12,000 \mathrm{~g}$ for 10 min at $4{ }^{\circ} \mathrm{C}$, and the supernatants were collected for protein concentration determination using a protein assay (Bio-Rad, Hercules, CA, USA). Protein samples $(30 \mu \mathrm{g})$ were separated on a sodium dodecyl sulfate-polyacryl-amide gel and transferred onto a nitrocellulose membrane.

The membranes were incubated with $5 \%$ skim milk in Tris-buffered saline containing $0.1 \%$ Tween-20 and then incubated overnight at $4{ }^{\circ} \mathrm{C}$ with the following primary antibodies: mouse $\beta$ actin antibody (1 : 1000; Santa Cruz Biotechnology, Santa Cruz, CA, USA), rabbit BDNF antibody (1 : 500; Santa Cruz Biotechnology), and rabbit TrkB antibody (1: 1000; Santa Cruz Biotechnology). Subsequently, the membranes were incubated for $1 \mathrm{~h}$ with secondary antibodies (1:2000; Cell Signaling), and detection was performed using the enhanced chemiluminescence (ECL) detection kit.

\section{Densitometry analysis}

Coronal sections of the hippocampus were examined from the rostral anteroposterior (- 2.1 $\mathrm{mm})$ to the anteroposterior $(-4.5 \mathrm{~mm})$ direction, as defined by the bregma of the brain atlas. Images were obtained at $10 \times$ magnification using the IMAGE PRO PLUS System (version 4.0; Media Cybernetics, Silver Spring, MD, USA) on a computer attached to a light microscope (Zeiss Axioskop, Oberkochen, Germany), which interfaced with a chargecoupled device video camera (Kodak Mega Plus model $1.4 \mathrm{I}$ ). To determine the density of the $A \beta$-immunoreactive staining in the hippocampus, a square frame of $500 \times 500 \mu \mathrm{m}^{2}$ was placed in the dorsal part of the hippocampus. A second square frame of 200 $\times 200 \mu^{2}$ was placed in the corpus callosum to measure the background. As previously described, variations in background illumination were controlled by subtracting the average background density of the corpus callosum from the average density of the hippocampus in each section analyzed [14].

\section{Statistical analysis}

Data are presented as mean \pm standard deviation (SD) and were analyzed by one-way ANOVA followed by Tukey's multiple comparison using SPSS 16.0 software for Windows. Differences were considered statistically significant at $p<0.05$.

\section{RESULTS}

\section{ATE reversed spatial learning deficits at 6 months of age in 3xTgAD mice}

To test the spatial memory, the performance of animals in the probe trial was compared to the time animals spent swimming to the platform. All animals were examined by a retention test that involved removing the platform from the pool.

Table 1: Effect of ATE on behavior in a Morris water maze $(n=8)$

\begin{tabular}{lc} 
Group & Escape latency(s) \\
\hline Control & $28.3 \pm 1.1$ \\
3xTg & $8.5 \pm 1.0^{\times \pi}$ \\
ATE-L & $13.4 \pm 1.4$ \\
ATE-H & $24.8 \pm 1.3^{\# \#}$ \\
\hline
\end{tabular}

Escape latency was determined using the hidden platform test. Significance was determined by Student's t test $\left(^{* *} p<0.01\right.$, compared with the control group; ${ }^{\# \#} p<0.01$, compared with the $3 \times \mathrm{Tg}$ group)

\section{Effect of ATE on $A \beta$ pathology in 3xTg-AD mice}

In 3xTg-AD mice, $A \beta$ is present in the hippocampus by 6 months of age. Therefore, to investigate the link between neurogenesis and the development of $A D$ pathology, the $A \beta$ burden in brains from $3 x T g-A D$ mice that receiving ATE treatments 3 month prior to 6 months of age was assessed. Amyloid $\beta$-protein $(A \beta)$ deposits in the CA1 region of the hippocampus were significantly increased in 6-month-old 3xTg animals compared to the age-matched WT group $(p<0.01)$. In the CA3 region of the hippocampus, $A \beta$ deposits were significantly increased in the $3 \times \mathrm{Tg}$ group $(p<0.001)$ when compared to the WT group $(p<0.01)$. Compared with the $3 \times \mathrm{Tg}$ group, $A \beta$ deposits in the CA1 region were significantly decreased by ATE 600 mg treatment $(p<0.05)$. In addition, compared with the $3 x \mathrm{Tg}$ group, $A \beta$ deposition in the CA3 significantly decreased after ATE $300 \mathrm{mg}$ dose of treatment $(p<0.05)$. However, there were no significant differences between the 3xTg group and the 3xTgp ATE (600 mg/kg) (Table 2).

\section{Effect of ATE on expressions of BDNF and TrkB in mouse hippocampus}

The effect of ATE treatment on the expression of hippocampal BDNF and TrkB in mice was determined. The results are shown in Table 3. The expressions of hippocampal BDNF and TrkB of $3 \times \mathrm{Tg}$ mice treatment with saline were significantly lower. 
Table 2: Effect of ATE on the deposition of $A \beta$ in the hippocampus $(\mathrm{n}=8)$

\begin{tabular}{lcc}
\hline Group & $\begin{array}{c}\text { Amyloid } \\
\text { beta } \\
\text { deposits in } \\
\text { CA1 (\% of } \\
\mathbf{3 x T g})\end{array}$ & $\begin{array}{c}\text { Amyloid beta } \\
\text { deposits in CA3 } \\
\text { (\% of 3xTg) }\end{array}$ \\
\hline Control & $59.7 \pm 1.5$ & $75.8 \pm 1.3$ \\
3xTg & $123.6 \pm 3.2^{\approx \pi}$ & $127.4 \pm 1.7^{\approx \pi}$ \\
ATE-L & $85.3 \pm 2.0$ & $97.5 \pm 2.1$ \\
ATE-H & $75.1 \pm 1.7^{\#}$ & $84.3 \pm 1.5^{\#}$ \\
\hline
\end{tabular}

The data are mean \pm SEM; $p<0.01$, compared with control mice; ${ }^{\#} p<0.05$, compared with $3 \times \mathrm{Tg}$ group (one-way ANOVA and Tukey's post-hoc tests)

Table 3: Effect of ATE on BDNF and TrkB expression in the hippocampus

\begin{tabular}{lcc}
\hline Group & $\begin{array}{c}\text { TrkB/beta } \\
\text { action ratio }\end{array}$ & $\begin{array}{c}\text { BDNF/beta action } \\
\text { ratio }\end{array}$ \\
\hline Control & $2.3 \pm 0.3$ & $2.3 \pm 0.3$ \\
3XTg & $0.8 \pm 0.4$ & $0.7 \pm 02$ \\
ATE-L & $1.3 \pm 0.6$ & $1.6 \pm 0.5$ \\
ATE-H & $1.9 \pm 0.2^{\#}$ & $1.9 \pm 0.4^{\#}$ \\
\hline${ }^{*} P<0.05$, compared to control mice; ${ }^{\#} p<0.05$, \\
compared to 3xTg mice (one-way ANOVA followed by \\
Tukey's post-hoc test)
\end{tabular}

\section{DISCUSSION}

The present study has demonstrated that ATE increased spatial learning, memory abilities, and the expressions of hippocampal BDNF and TrkB in 3xTg-AD mice. In the present study, 3xTg-AD mice were used, a model derived from APPS we , $P S 1_{\mathrm{M} 146 \mathrm{~V}}$, and tau $301 \mathrm{~L}$ transgenes. The $3 \times \mathrm{Tg}-\mathrm{AD}$ mice develop a progressive, age-related neuropathological phenotype that includes plaque and tangle pathologies. Both of these hallmark lesions are mainly limited to the hippocampus, amygdala, and cerebral cortex the brain structures most impacted by $A D$ pathology [15].

Cognitive impairment has been detected in 2month-old 3xTg-AD mice [16], and $A \beta$ deposits in the hippocampus and cortex have been found in 6-month-old 3xTg-AD mice [17-19]. These findings indicate that the pathological features that imitate $A D$ in $3 \times T g A D$ mice remain stable. Classic symptoms of $A D$ include problems with spatial learning and memory deficits. The study demonstrated that treatment with ATE resulted in a significant restoration of spatial learning and memory function in AD mice. These results suggest that ATE treatment may be effective in ameliorating cognitive impairment caused by AD.

Neuron-specific nuclear antigen (NeuN) is a neuronal-specific nuclear protein $[20,21]$. The expression of $\mathrm{NeuN}$ is observed in most neuronal cell types throughout the nervous system, with the exception of some neuronal populations that are NeuN-negative, but does not stain nonneuronal cells [22]. NeuN is a soluble nuclear protein that is localized to the cell nucleus and in the neuronal cytoplasm of post-mitotic neurons. Within the hippocampus, NeuN can be used as a marker of postmitotic cells and labels both "normal" postmitotic neurons and newly generated postmitoticneurons. The BDNF plays pivotal roles in learning, memory, and neuronal plasticity.

The levels of BDNF, and its main receptor TrkB, have been reported to lessen in $A D$. It was hypothesized that BDNF and its receptor may be involved in the protective role of ATE against memory impairment. Results of the present study have demonstrated that ATE intake significantly increases the expression of BDNF and its main receptor TrkB, in the brain, which is in agreement with the hypothesis. There is evidence to support the results. It has been demonstrated that BDNF and TrkB, are capable of protecting against memory impairment and regulate neurogenesis in the hippocampus of $A D$. A recent study also supports the role of BDNF signaling through TrkB in the pathophysiology and cognitive and its receptor involving ATE in AD [23].

\section{CONCLUSION}

This study reveals that ATE attenuates learning and memory deficits in 3xTg-AD mice, Therefore, the plant extract can potentially be developed as a therapeutic agent for the management of $A D$ in humans.

\section{DECLARATIONS}

\section{Conflict of interest}

No conflict of interest is associated with this work.

\section{Contribution of authors}

We declare that this work was done by the authors named in this article and all liabilities pertaining to claims relating to the content of this article will be borne by the authors. Ping Niu designed all the experiment and revised the paper. Cen Su, Yao-ming $\mathrm{Xu}$ and Ye Feng performed the experiment, Hai-ping Xia wrote the paper.

\section{Open Access}

This is an Open Access article that uses a fund- 
ing model which does not charge readers or their institutions for access and distributed under the terms of the Creative Commons Attribution License (http://creativecommons.org/licenses/by/ 4.0) and the Budapest Open Access Initiative (http://www.budapestopenaccessinitiative.org/rea d), which permit unrestricted use, distribution, and reproduction in any medium, provided the original work is properly credited.

\section{REFERENCES}

1. Billings $L M$, Oddo $S$, Green KN, McGaugh JL, LaFerla FM. Intraneuronal Abeta causes the onset of early Alzheimer's disease-related cognitive deficits in transgenic mice. Neuron 2005; 45: 675-688.

2. Chadwick W, Mitchell N, Caroll J, Zhou Y, Park SS. Amitriptyline-mediated cognitive enhancement in aged $3 \times T g$ Alzheimer's disease mice is associated with neurogenesis and neurotrophic activity. PLOS One 2011; 6: 21660-21662.

3. Chen $W$, Cheng $X$, Chen J, Yi X. Lycium barbarum polysaccharides prevent memory and neurogenesis impairments in scopolamine-treated rats. PLoS One 2014; 9: 88076-88078.

4. Chung YC, Kim SR, Park JY. Fluoxetine prevents MPTPinduced loss of dopaminergic neurons by inhibiting microglial activation. Neuropharmacol 2011; 60: 963974.

5. Geloso MC, Corvino V, Cavallo V, Toesca A, Guadagni E, Passalacqua R, Michetti F. Expression of astrocytic nestin in the rat hippocampus during trimethyltininduced neurodegeneration. Neurosci Lett 2004; 357 : 103-106.

6. Geloso MC, Vercelli A, Corvino V, Repici M, Boca M, Haglid K, Zelano G, Michetti F. Cyclooxygenase-2 and caspase 3 expression in trimethyltin-induced apoptosis in the mouse hippocampus. Exp Neurol 2002; 175: 152 160.

7. Herculano-Houzel $S$, Lent R. Isotropic fractionator: a simple, rapid method for the quantification of total cell and neuron numbers in the brain. $J$ Neurosci 2005; 25 . 2518-2521.

8. Hsiao $\mathrm{YH}$, Hung $\mathrm{HC}$, Chen $\mathrm{SH}$, Gean PW. Social interaction rescues memory deficit in an animal model of Alzheimer's disease by increasing BDNF-dependent hippocampal neurogenesis. J Neurosci 2014; 34: 16207-16219.

9. Hubka P. Neural network plasticity, BDNF and behavioral interventions in Alzheimer's disease. Bratis/ Lek Listy 2006; 107: 395-401.

10. Li XY, Guo F, Zhang QM, Huo TT, Liu LX, Wei HD, Xiong $L Z$, Wang $Q$. Electroacupuncture decreases cognitive impairment and promotes neurogenesis in the APP/PS1 transgenic mice. BMC Complement. Altern. Med. 2014; 14: 37 - 39.

11. Lind D, Franken S, Kappler J, Jankowski J, Schilling K. Characterization of the neuronal marker NeuN as a multiply phosphorylated antigen with discrete subcellular localization. J Neurosci Res 2005; 79: 295-302.

12. European Commission [homepage on the internet]. Directive 2010/63/EU on the protection of animals used for scientific purposes [cited 2013 Jan 16]. Available from:http://ec.europa.eu/environment/chemicals/lab_ani mals/legislation_en.htm.

13. Morris R. Developments of a water-maze procedure for studying spatial learning in the rat. $J$ Neurosci Methods 1984; 11: $47-60$.

14. Mullen RJ, Buck CR, Smith AM. Neu N. a neuronal specific nuclear protein in vertebrates. Development 1992; 116: 201-211.

15. Nagahara AH, Merrill DA, Coppola G, Tsukada S, Schroeder BE, Shaked GM, Wang L, Blesch A. Neuroprotective effects of brain-derived neurotrophic factor in rodent and primate models of Alzheimer's disease. Nat Med 2009; 15: 331-337.

16. Oddo S, Caccamo A, Shepherd JD, Murphy MP, Golde TE, Kayed R, Metherate R, Mattson MP, Akbari $Y$, LaFerla FM. Triple-transgenic model of Alzheimer's disease with plaques and tangles: intracellular Abeta and synaptic dysfunction. Neuron 2003; 39: 409-421.

17. Oddo S, Caccamo A., Tran L, Lambert MP, Glabe CG, Klein WL, LaFerla FM. Temporal profile of amyloid-beta (Abeta) oligomerization in an in vivo model of Alzheimer disease. A link between Abeta and tau pathology. J Biol Chem 2006; 281: 1599-1604.

18. Park HJ, Shim HS, Choi WK, Kim KS, Bae H, Shim I. Neuroprotective effect of Lucium chinense fruit on trimethyltin-induced learning and memory deficits in the rats. Exp Neurobiol 2011; 20: 137-143.

19. Ritter JM. Drugs for Alzheimer's disease. Br J Clin Pharmacol 2012; 73: 501-503.

20. Selkoe DJ. Images in neuroscience. Alzheimer's disease: from genes to pathogenesis. Am J Psychiatry 1997; 154: 1198-1201

21. Xiao Y, Harry GJ, Pennypacker KR. Expression of AP-1 transcription factors in rat hippocampus and cerebellum after trimethyltin neurotoxicity. Neurotoxicol 1999; 20: 761-766.

22. Ye M, Lee SG, Chung ES, Lim SJ. Neuroprotective effects of cuscutae semen in a mouse model of Parkinson's disease. Evid Based Complem Altern Med 2014; 2014: 150153-150155.s

23. Yu MS, Leung SK, Lai, SW, Che CM, Zee SY, So KF, Yuen WH, Chang RC. Neuroprotective effects of antiaging oriental medicine Lycium barbarum against betaamyloid peptide neurotoxicity. Exp Gerontol 2005; 40: 716-727. 